\title{
Chapter 30 \\ Social Policy for Older People in the Post- Soviet Space: How Do Pension Systems and Social Services Influence Social Exclusion?
}

\author{
Irina Grigoryeva, Oksana Parfenova, and Alexandra Dmitrieva
}

\subsection{Introduction}

Various approaches currently exist to conceptualising and measuring social exclusion (Burchardt and Le Grand 2002; Walsh et al. 2017). By expanding the concept of poverty and material limitations, researchers have shown that exclusion can be defined not only as a lack of financial opportunities, but also as a sum total of various barriers (in education, access to healthcare, labour market participation etc.) that jeopardise an individual's or a group's social and systemic integration (Sen 1999). Exclusion has begun to be interpreted as not only material, but also symbolic limitations, a disruption of social and symbolic connections (Silver 1994). The vertical class stratification has been replaced by a horizontal differentiation that distinguishes insiders from outsiders (Abrahamson 2001). In this sense, both individuals and specific groups of people may experience forms of social exclusion (Levitas et al. 2007). The social status of older people, particularly in the post-Soviet space, is characterised by multiple structural barriers that prevent them from enjoying an active lifestyle. Some of these barriers are hard to overcome, as they have to do with older people's state of health. Older people can become marginalised not only through financial insecurity, but also through loss of social contacts linked to the workplace and a reduced ability to socialise with friends and family. The latter is of growing relevance as a result of strong family nuclearisation (Eliseeva and Kletsin 2010).

\footnotetext{
I. Grigoryeva $(\square)$

University of St. Petersburg, St. Petersburg, Russia

e-mail: soc28@yandex.ru
}

O. Parfenova

Sociological Institute of FCTAS RAS, St. Petersburg, Russia

\author{
A. Dmitrieva \\ Support, Research and Development Center (SRDC), Kyiv, Ukraine
}


Evidence from European Union (EU) member states suggests that older adults experience less social exclusion in countries with greater levels of social protection, with income and health conditions having more impact on social exclusion than age and gender (Jehoel-Gijsbers and Vrooman 2008). A recent scoping review identified six key domains relating to social exclusion of older people: neighbourhood and community; services, amenities and mobility; social relations; material and financial resources; socio-cultural aspects; and civic participation (Walsh et al. 2017). In our analysis, we consider policies relating to pensions and social services, which belong to the material and financial resources and services, amenities and mobility domains, respectively.

Against this background, post-Soviet countries illustrate the complexity of challenges relating to social exclusion, as later life in these countries is marked by relatively poor health, low life expectancies, and reduced quality of life. Using the examples of Russia and Ukraine, this chapter examines characteristics of the two most important spheres of social welfare, pension provision and social services, and considers how these are changing. Using the examples of Russia and Ukraine, we pose the question: how do modern pension reforms and the structure of social services in the post-Soviet space affect the social exclusion of older people? Russia and Ukraine were chosen because they illustrate important policy trends, given their ageing populations, both countries have rather lagged behind other post-Soviet states in introducing vital pension reforms and in reforming social services for older people. Moreover, pension reforms in both countries began almost simultaneously in 2018 in Ukraine and 2019 in Russia - and continue to progress at the time of writing.

Starting from the 1990s, falling living standards could be observed across the entire post-Soviet space due to inflation and cuts in pension benefits. Researchers who analyse the overhaul of Russian social policies in the new market environment consider post-Soviet bureaucracy, unable to adapt to the new market conditions, to be the main obstacle to reform (Cook 2007; Grigoryeva 2017). Examining the transformation of the post-Communist "legacy" into Russian social policies, Cook (2007) concluded that by 2007 the sphere of social security in Russia manifested a relatively low level of social security and excluded a significant portion of the population from basic services and social insurance and service provision. One can counter her argument by pointing out that, at the time, everyone was and still is covered by compulsory medical insurance and universal pension insurance or provision. Persons falling short of the length of service required for an occupational pension receive a social pension. Contemporary studies into Russian state-operated services for older people show, however, that there is now even more bureaucracy in the sphere of social services, and that has become a problem not only for older service users but also for service providers (Parfenova 2018; Grigoryeva et al. 2019a, b; also see Széman et al. this volume).

In considering our research question in the sections that follow, we draw on an analysis of legislation relating to pension and social services reforms in Russia and Ukraine, publicly available statistical data, and evidence from research conducted in both countries. 


\subsection{The Russian Case}

The need to reform the pension system, modify its parameters, and give more careful consideration to individual insurance rights (unaccounted for due to closure of numerous companies and their employees having no documentation to prove their length of service), has been discussed in Russia since the mid-1990s. A series of laws have been passed to that effect, including, for example, the law On Individual (Personalised) Accounting in the Compulsory Pension Insurance System, and all citizens now receive an individual social security card (FL 27, 1996). This has, however, proved to be a mere formality. The new law had no effect on pension payments, since these are calculated based not on the data thus accounted for, but on a special averaging formula. In 2001, basic laws on pension provision (FL 166, 2001) and pension insurance (FL 167, 2001) were adopted that made provisions for a three-pillar pension consisting of old-age security, insurance payments, and personal savings. However, due to companies constantly being in tax arrears and the Pension Fund of the Russian Federation growing ever more dependent on transfers from the state budget, actual pension payments failed to exceed the minimum wage and did not keep pace with inflation.

Also noteworthy is the falling average life expectancy across the post-Soviet space, especially among men. By the mid-2010s, this tendency had considerably slowed down, but average male life expectancy has not yet reached 70 years, as was the case during the Soviet era. It was exactly this relatively short average lifespan and, especially, the low healthy life expectancy that constituted the principal argument against increasing retirement ages. For men, the relatively short post-retirement survival period has persisted, and the gender gap has remained static. In comparison with Russia's nearest neighbours, such as Finland, and other post-Soviet states, Russia has the shortest length of life (including healthy life expectancy) among both men and women (Table 30.1).

The requirement for pension reform was nevertheless constantly felt and brought up in Russia, as well as in the Ukraine. The government of the Russian Federation announced the launch of the pension reform on $14^{\text {th }}$ June 2018 . Two days later, a draft of the federal law On Amendments to Certain Legal Acts of the Russian Federation Regarding the Granting and Payment of Pensions was introduced for

Table 30.1 Life expectancy and healthy life expectancy

\begin{tabular}{l|l|l|l|l}
\hline \multirow{2}{*}{ Country } & \multicolumn{2}{|l|}{$\begin{array}{l}\text { Average life expectancy at birth } \\
\text { (years) }\end{array}$} & $\begin{array}{l}\text { Average healthy life expectancy at } \\
\text { birth (years) }\end{array}$ \\
\hline & Men & Women & Men & Women \\
\hline Russia & 66.4 & 77.2 & 59.1 & 67.5 \\
\hline Ukraine & 67.6 & 77.1 & 60.3 & 67.6 \\
\hline Finland & 78.7 & 84.2 & 69.8 & 73.5 \\
\hline Estonia & 73.1 & 82.1 & 64.6 & 71.4 \\
\hline Armenia & 71.2 & 78.1 & 63.6 & 68.7 \\
\hline
\end{tabular}

(Source: World Health Organization, 2016)

http://apps.who.int/gho/data/view.main.SDG2016LEXv?lang=en 
consideration into the State Duma (Parliament). The main feature of the reform was that retirement age would increase gradually, over a 10-year period (i.e. by 2028), to 60 years for women and 65 years for men. The length of pensionable service required to receive an occupational pension would increase to 15 years as early as 2025 .

In Russia, prior to the reform, social pensions were available to women from age 55 and to men from age 60 (FL 166, 2001). One of the latest versions of this regularly updated law instantaneously raised the age of retirement to 60 years for women and 65 years for men. This immediately produced a group of around three million people who were to receive no pension whatsoever. The only income transfers they are entitled to are social welfare payments. The most recent amendment of the same law will see these age norms increase by five additional years, to 65 and 70 years respectively for women and men (FL 350, 2018).

In this case, changes will not be implemented immediately but will follow a stipulated timeline from 2019 to 2023 . Notably, retirement age for social pension recipients is planned to increase more rapidly than in the case of occupational pensions. The latter are governed by an act that is largely incomprehensible to ordinary citizens concerning the length of pensionable service; according to this act, in 2008 one needed no less than 5 years of service to qualify for an occupational pension. Subsequently, the state increased the required length of service, so that in 2019 an applicant needs to show at least 9 years of employment, and by 2025 the requirement will increase to at least 15 years of employment. However, the difference between an old-age pension with minimal length of pensionable service and that with, say, 30 years of service is insignificant. The average monthly occupational pension awarded on $1^{\text {st }}$ January 2019 amounts to 14,102 RUB (€196), whereas a social pension equals 9904 RUB (€137) (Federal State Statistics Service 2019). Such a negligible difference discourages people from contributing to the national pension scheme or to other social insurance funds. Instead, people frequently declare a fictitious minimum wage, so the employer would pay only minimal social contributions.

Research on employment in retirement in contemporary Russia suggests that many people continue to work after reaching statutory retirement age. They often do so not so much for the extra income as for the desire to remain included in an active social life. Moreover, while older people remain capable of continuing their education, they are limited by common prejudices and the inadequacy of the state's social policies (Rogozin 2012; Grigoryeva et al. 2019a, b). Studies of older people's labour potential in Russia suggest that the situation regarding post-retirement employment will improve once people with sufficient educational resources and the skills necessary to work with new technologies start to retire (Smolkin 2014). However, it is worth noting that different groups of pensioners have different motivations for continuing to work. While some people do not want to retire, others continue to be employed in informal ways for many years.

Along with the pension system transformation, the development of social services for older people took off at the end of the Soviet period. A system of social work and social services, as we currently understand them, began to evolve in Russia 
in the early 1990s. Development took place in three directions simultaneously: as a system of professional training; conceptualisation of emerging practices and adaptation of theoretical approaches in the Russian context; and a system of social services (social practices) for the population. At present, after the Pension Fund of the Russian Federation, the most notable actor in the sphere of social support is a network of state-operated specialised centres and branches of home care services for older people and persons with disabilities. Home-based care grew rapidly in Russia from late 1980s and early 1990s and by 2017 over one million citizens were being supported by such centres and branches [also see Széman et al. this volume]. This is over five times the number of older people receiving social and socio-medical care in state-operated nursing homes. In 2016, there were 253,382 people living in nursing homes across Russia (Rosstat 2018).

In 2015, a new federal law on social services was passed (Federal Law 442). Transformations that took place in the sphere of social services are best considered in the context of a neoliberal turn. Research suggests that, in practice, liberalisation is limited to a significant increase in service fees, some relaxation of the rules regarding access to services (people can receive services wherever they live rather than only at their registered domicile), and involvement in social services of nongovernmental and commercial organisations (Parfenova 2018). Social workers receive higher wages, offset by an increased workload and staff cuts. Paradoxically, along with fee increases and an expanded list of services provided, new regulations also rigidly limit the amount of time allotted for service provision and make it impossible to flexibly modify the number and type of services a client requires. All of this leads to constant manoeuvering both by service recipients and providers forced to replace certain services with others and, consequently, to mutual discontent. The passing of FL 442 did not make the situation for clients cared for at home any better; to the contrary, they were aggravated by increased fees and additional bureaucracy. Due to lack of information or by force of habit in a situation when alternative arrangements are available through non-governmental organisations, older people tend to prefer a governmental service. While experts from stateoperated social service centres give the situation a reflexive and critical assessment, their opinions and wishes are not taken into account by the relevant authorities. In the regions (especially in rural areas), NGOs and commercial organisations are virtually non-existent (Parfenova 2018). Apparently, the more functional and flexible services offered by NGOs and commercial organisations lose out to the rather rigid and limited, but "reliable and familiar" state services, the preservation of which is in the interest of all levels of the existing system of social services. Older adults themselves most likely lack information and stick to the familiar format of service. On the whole, in rural areas one can observe an increasing role of informal relations in the sphere of adult social care [see Széman et al. this volume for a more in-depth discussion of the home care provisions in Russia].

Research on social exclusion in the Russian context distinguishes seven parameters of social exclusion: work; health; education and culture; relationships; connections; autonomy; and housing (Tikhonova 2004). When applied to older people with restricted mobility in contemporary Russia, these parameters acquire a specific 
meaning. Our inquiry into the clients of state-operated social services highlights a number of key points. The category of "work" is practically irrelevant for older people due to poor health. Those who receive home-based social services from the state are, by and large, unfit for work, with some having ceased employment upon retirement. In relation to "health", the situation is also idiosyncratic. In theory, older people have access to medical services. Moreover, they frequently enjoy a certain number of privileges relating to health care. However, older people's state of health is typically so poor that even going to a doctor is often problematic. Physical limitations due to poor health have a visible impact on older adults' lifestyles, with recipients of home-based social services either rarely or never leaving their homes. Things are different for "mobile" service users whose health condition does not prevent them from benefitting from integration measures offered by social services centres. The category of "education and culture" in this case may be seen as elusive. Homebased clients of social services cannot, in fact, satisfy their current needs for education and culture due to poor health, whereas clients from the mobile group, capable of attending excursions and classes, have opportunities for social integration. The category of "connections" is presently hard to assess, while the category "relationships", as our study shows, also draws a distinction between mobile and less mobile older people (Parfenova 2017). In the absence of physical limitations, people who are mobile have more opportunities for integration in communities, both through state-operated social centres and on their own. Disabled service users, nevertheless, get a chance to expand their communicative space through contact with a social worker. The category "autonomy" pre-supposes physical fitness as the major prerequisite for active participation in social life. Thus this parameter is only applicable to mobile service users. In relation to the final category, housing, most clients are provided with accommodation, so no special practices of exclusion are to be found here. Rather, the opposite is true: home-based services are not infrequently required by older people living alone in a place of their own (Parfenova 2017).

\subsection{The Ukranian Case}

Turning to the case of policy relating to social exclusion of older people in Ukraine, a useful starting point is that expenditure attributed to people of pensionable age represents over $50 \%$ of the total Ukrainian social security budget. This is due to the ageing population and a relatively low retirement age, leading to a greater number of persons above the cut-off age, as well as a considerable array of privileges granted to older people (for example, all pensioners have a right to free travel on municipal and peri-urban public transit).

Over the long term, issues associated with the stability and efficacy of the Ukrainian pension system are related to demographic trends, in particular to low fertility and the progressive ageing of the country's population. By 2050, the ratio of persons over 65 years of age to those aged 15-64 is forecast to increase to $38 \%$, and that between pensioners and those paying pension contributions, to $132 \%$ 
(Social Care 2009). Throughout the post-Soviet period, informal (unregulated) employment on a large scale has characterised the Ukrainian economy, leading to practices of income under-declaration and tax evasion. Even when labour relations were properly formalised, a significant portion of income remained undeclared (in the form of cash payments). Thus, the shortage of funds in the Pension Fund has as much to do with population ageing as with widespread unregulated employment.

Pension reform in Ukraine was introduced in 2018. To this effect, on $3^{\text {rd }}$ October 2017 the Supreme Rada (parliament) adopted the Law of Ukraine №2148-VIII, and, after, The Law No 2449-VIII. The reform introduced gradual changes to a number of pension system parameters over the subsequent 10 years (i.e. until 2027). At the core of these changes is the length of pensionable service, which should be 35 years for retirement at age 60. Thus, the Ukrainian pension reform focuses on "legalising" pensionable service, that is, returning labour market and employment to the situation that allows for statutory pension insurance and pension calculation based on length of pensionable service and salary. Immediately, starting from 2018, previously awarded pensions were recalculated based on the average salary in the 3 years preceding retirement (from 2014 to 2016). They currently amount to $3764 \mathrm{UAH}$ (approximately €120) monthly. However, the minimum pension is very small, amounting to only $1564 \mathrm{UAH}$ (approximately $€ 50$ monthly). As of 2019, pensions will be calculated based on the average salary in the last 3 years of employment and the cost of 1 year of pensionable service equivalent to $1 \%$. Prior to the reform, the coefficient was equal to $1.35 \%$. In fact, the regulation that the statutory pension is to be calculated based on the average salary of the 3 years preceding retirement is similar to the calculation used during the Soviet period, except that at this earlier time it was the final 2 years of service that calculations were based on. This condition obviously encourages people to access regularised employment, with a reported salary, at least in the last few years before reaching retirement age.

While the statutory age of retirement has formally remained the same, at 60 years for both men and women, in practice requirements for pensionable service have become more stringent. From 2018 onwards, only those Ukrainians are qualified to retire at 60 who have worked and paid pensionable contributions for 25 years and more. Every year, requirements regarding the length of pensionable service will increase by 12 months per year. Thus by 2028 , one would need 35 years of pensionable service in order to retire at age 60 . In contemporary society, where education and training take up a significant portion of one's life, this will not be straightforward. People falling short of 35 years of pensionable service will only be able to retire at 63 or even 65 years of age. Should someone have under 15 years of pensionable service by the age of 65 , they will receive no pension at all. Instead, they will be entitled to receive means-tested social assistance payments, the size of which will be based on the older person's household income.

The Ukrainian pension reform has made provisions for temporary social assistance to citizens in the period between $1^{\text {st }}$ January 2018 and $31^{\text {st }}$ December 2020. It is granted to persons unfit to work who have reached retirement age and have at least 15 years of pensionable service, but no right to an occupational pension. Financial assistance will be provided until the persons who have become unfit to 
work have reached the age of entitlement to old-age income transfers, equivalent to a minimum wage. Academy member E.M. Libanova, one of the authors of the reform, believes that these 3 years will give people time to acquire all proof of earlier employment not formalised at the time or to have worked the requisite length of time needed to increase their pensionable service and the size of pension, respectively (Libanova 2017). Citing E.M. Libanova, Novosti Ukrainy note that "for a number of years, people were reluctant to receive an officially reported salary". There are still a lot of people in Ukraine who wish to subsist on social assistance alone:

"Recently at an employers meeting in Ivano-Frankivsk, someone stated that he would be willing to pay up to $15,000 \mathrm{UAH}$, but his employees requested that he pay them less, albeit under the table. That is, a person wishes to receive a salary, but also not to give up a state subsidy of 3,000 UAH, and this government money means more to them than the same 3,000 UAH they could have earned officially" (Maksimovich 2018).

Social services in the Ukraine were formalised through normative acts somewhat later than in Russia, namely in 2003 in a law entitled On Social Services (The Law of Ukraine 2003). For instance, Article 5 of this law makes provisions for two forms of social care: financial assistance and social services. Part 4 of Article 5 of the law defines such social services as social welfare facilities, psychological, sociopedagogical, socio-medical, socio-economic, legal, advisory services, as well as help with employment and other pratices. This classification is similar to its Russian counterpart. It remains uncertain and incomprehensible precisely which services are included in the "material service". As in Russia, the concepts of service, support, help, protection and such, lack clear definitions and are closely related and thus often overlap. However, in Ukraine, "non-state-operated providers of social services, such as charities and religious organizations, as well as natural persons whose activities have to do with providing social services have become widespread" earlier than in Russia (Gorova 2012, p.446).

\subsection{Conclusion}

Responding to our principal question of how, using the examples of Russia and Ukraine, recent pension reforms and the structure of social services in the postSoviet space affect the social exclusion of older people is far from straightforward. In theory, pension reforms in both countries ought to have extended the period of paid employment and increased social inclusion of older adults. However, in practice. The reforms have reduced older people's real incomes. While older people were once able to receive a salary alongside their pension on reaching statutory retirement age, they now have to wait for this opportunity for a few more years. The group at greatest risk of social exclusion in terms of their material circumstances are those older adults who live alone and are no longer able to work due to poor health or a lack of suitable employment, especially in rural areas. In these circumstances, older 
people have limited opportunities to receive help and support from other sources. Low income, with an average pension equalling 14,151 RUB, (approximately €196 monthly; Russian Pension Foundation 2019), restricted mobility, and a narrow choice of care providers make such individuals most vulnerable to risks of exclusion.

In relation to pension provisions, fair accounting and assessment of pensionable service should be prioritised by policymakers. Moreover, peculiarities typical of older people in post-Soviet nations hinder both pension reform and modernisation of social services. The current cohort of older adults was the first to see itself as "the lost generation". They consider themselves to have been victims of rapid socioeconomic change. These people intended to retire according to "Soviet" rules and to receive a decent pension, in spite of the many years that have passed since the fall of the USSR. However, in reality, they did not receive a decent pension and came to realise that they may never again have secure employment comparable to that which they had prior to retirement. At only 60-65 years of age, these pensioners have not yet lost much in terms of qualifications and fitness to work. In practice, employment services offer older people only those vacancies that require few or no qualifications. As a result, in post-Soviet countries, such as Russia and Ukraine, the social elevator only works in one direction in later life - downwards.

Thus, low income combines with chronic illnesses and difficulty accessing quality medical services, especially in remote rural areas, as well as a very basic form of social care offered by monopolistic state-operated service providers. In our view, the combination of these factors serves as the key factor influencing the social exclusion of older people in the post-Soviet space. With pensions and social services representing sub dimensions of exclusion from material and financial resources and from services, amenities and mobility (Walsh et al. 2017), we assume that exclusion in these areas also shapes exclusion in other domains. However, this requires further research and conceptual development. As for modern state policy in Russia and Ukraine, we can identify a need for state policies to focus more strategically on preventing illness, increasing healthy life expectancy, and promoting the practice of self-care in order to reduce risks of social exclusion in older-age.

\section{Editors' Postscript}

Please note, like other contributions to this book, this chapter was written before the COVID-19 pandemic of 2020. The book's introductory chapter (Chap. 1) and conclusion (Chap. 34) consider some of the key ways in which the pandemic relates to issues concerning social exclusion and ageing.

Acknowledgments The research for the introduction and sections on Russia, conducted by I. A. Grigoryeva, was supported by the Russian Science Foundation (project №19-18-00246 "Challenges of the transformation of Welfare State in Russia: institutional changes, social investment, digitalization of social services"). 


\section{References}

Abrahamson, P. (2001). Social exclusion and poverty [Abrahamson P. Social'naja jekskljuzija i bednost']. Obshhestvennye nauki i sovremennost' - Social Sciences and Modernity, (2), $158-166$.

Burchardt, T., \& Le Grand, J. (2002). Degrees of exclusion: Developing a dynamic, multidimensional. In J. Hills, J. Le Grand, \& D. Pichaud, Understanding social exclusion (pp. 30-43). New York: Oxford University Press.

Cook, L. J. (2007). Postcommunist welfare states. Reform politics in Russia and Eastern Europe. Ithaca: Cornell University Press.

Eliseeva, I., \& Kletsin, A.A. (2010). Urban family in Russia: Current trends. Petersburg Sociology Today [Peterburgskaya sotsiologiya segodnya], (2): 127-146. (in Russian).

Federal State Statistics Service (Rosstat). (2019). https://www.gks.ru/storage/mediabank/doc3-1-1. htm. Accessed 22 Sept 2019.

Gorova, A. V. (2012). Nederzhavnyy sektor nadannya sotsial'nykh posluh: suchasnyy stan ta perspektyvy rozvytku. In S. V. Kivalov (Ed.), Aktual'ni problemy derzhavy i prava: Zbirnyk naukovykh prats' (Vol. 63, pp. 445-450). Odesa: Yurydychna literatura. (In Ukrainian).

Grigoryeva, I. A. (2017). One hundred years of social policy in Russia. The Journal of Social Policy Studies, 15(4), 495-496.

Grigoryeva, I. A., Sizova, I. L., \& Moskvina, A. Y. (2019a). Social services for the elderly: Implementation of the Federal Law No. 442 and future prospects. Monitoring of Public Opinion: Economic and Social Changes, 4, 125-144. https://doi.org/10.14515/monitoring.2019.4.09.

Grigoryeva, I., Vidiasova, L., Dmitrieva, A., \& Sergeyeva, O. (2019b). Elderly population in Modern Russia: Between work, education and health. Springer.

Jehoel-Gijsbers, G., \& Vrooman C. (2008). Social exclusion of the elderly: A comparative study of EU Member (ENEPRI Research Report No. 57). Available at SSRN: https://ssrn.com/ abstract $=2027886$. Accessed 22 Sept 2019.

Levitas, R., Pantazis, C., Fahmy, E., Gordon, D., Lloyd, E., \& Patsios, D. (2007). The Multi-dimensional analysis of social exclusion. Bethesda: Bristol Institute for Public Affairs, University of Bristol.

Libanova, E. M. (2017). Ministerial conference on ageing: A sustainable society for all ages: Realizing the potential of living longer. UNECE conference (pp. 21-22). Lisbon. http://www. unece.org/pau/ageing/ministerial_conference_2017.html. Accessed 10 Aug 2019.

Maksimovich, M. (2018). Sociologist: Ukrainians are used to relying only on the state. News of Ukraine. https://replyua.net/news/106356-sociolog-ukraincy-privykli-polagatsya-tolko-nagosudarstvo.html. Accessed 20 Sept 2019.

Parfenova, O. (2017). Care for the old people in state social services. PhD dissertation. https:// search.rsl.ru/ru/record/01006654185. Accessed 22 Sept 2019 (in Russian).

Parfenova, O. (2018). Transformation of social services for the elderly in the regional context of modern Russia. The Journal of Sociology and Social Anthropology [Zhurnal sotsiologii i sotsialnoy antropologii], 21(2), 165-186. https://doi.org/10.31119/jssa.2018.21.2.6. (in Russian).

Rogozin, D. M. (2012). The liberalization of aging, or labor, knowledge and health at an older age. Sociological Journal, 4, 62-93. (in Russian).

Rossat. (2018). http://www.gks.ru/wps/wcm/connect/rosstat_main/rosstat/ru/statistics/population/ generation/\#

Russian Pension Foundation. (2019). https://pfrp.ru/faq/srednyaya-pensiya-v-rossii.html. Accessed 10 Aug 2019.

Scharf, T., \& Keating, N. (Eds.) (2012). Social exclusion in later life: A global challenge. Bristol: The Policy Press.

Sen, A. (1999). Development as freedom (1st ed.). New York: Oxford University Press.

Silver, H. (1994). Social exclusion and social solidarity: Three paradigms. International Labour Review, 133(5-6), 531-578. 
Smolkin, A. A. (2014). The labor potential of the elderly. Sociological Studies, 5, 97-103. (in Russian).

Social Care and Social Inclusion in Ukraine. (2009). Ukrainian center for social reforms Kiev. http://www.ucsr.kiev.ua/public_en.html. Accessed 22 Sept 2019.

Tikhonova, N. (2004). Social exclusion in Russia. In N. Manning \& N. Tikhonova (Eds.), Poverty and social exclusion in the New Russia (pp. 109-149). London: Ashgate.

Walsh, K., Scharf, T., \& Keating, N. (2017). Social exclusion of older persons: A scoping review and conceptual framework. European Journal of Ageing, 14(1), 81-98.

World Health Organization. (2016). Life expectancy and Healthy life expectancy. Data by country. https://apps.who.int/gho/data/view.main.SDG2016LEXv?lang=en. Accessed 3 December, 2020.

\section{Legal Acts}

Federal Law N 166-FL on December 15, 2001 'On State Pension Provision in the Russian Federation'.

Federal Law N 167-FL on December 15, 2001 "On Compulsory Pension Insurance in the Russian Federation".

Federal Law N 350-FL on October 3, 2018, 'On Amendments to Certain Legislative Acts of the Russian Federation on the Purpose and Issues of Pensions'.

Federal Law N 422-FL on December 28, 2013 'About Bases of Social Services Of Citizens in the Russian Federation'.

Federal Law of Russia N 27-FL on April 1, 1996 'On individual (personified) accounting in the system of compulsory pension insurance'.

The Law of Ukraine №2148-VIII, 03 October 2017. On Amendments to Some Legislative Acts of the Ukraine Regarding Pension Increases. he Law of Ukraine No. 966-IV on June 19, 2003 'On Social Services'.

The Law of Ukraine. No. 2449-VIII on June 7, 2018. 'On introducing an amendment to the relevant legislative acts of Ukraine on pension'.

Open Access This chapter is licensed under the terms of the Creative Commons Attribution 4.0 International License (http://creativecommons.org/licenses/by/4.0/), which permits use, sharing, adaptation, distribution and reproduction in any medium or format, as long as you give appropriate credit to the original author(s) and the source, provide a link to the Creative Commons license and indicate if changes were made.

The images or other third party material in this chapter are included in the chapter's Creative Commons license, unless indicated otherwise in a credit line to the material. If material is not included in the chapter's Creative Commons license and your intended use is not permitted by statutory regulation or exceeds the permitted use, you will need to obtain permission directly from the copyright holder.

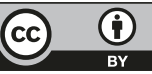

